\title{
Mutations that disable the DNA repair gene XPG in a xeroderma pigmentosum group $\mathbf{G}$ patient
}

\author{
Thierry Nouspikel and Stuart G.Clarkson* \\ Department of Genetics and Microbiology, Centre Médical Universitaire (CMU), 9 avenue de Champel, 1211 Geneva 4, Switzerland
}

Received March 3, 1994; Revised and Accepted March 30, 1994

EMBL accession nos $X 69978$ and $X 78329$

The human XPG (ERCC5) gene encodes a large acidic protein that corrects the ultraviolet light sensitivity of cells from both xeroderma pigmentosum complementation group $G$ and rodent ERCC group 5. Here we characterize five XPG sequence alterations and a minor splicing defect in XP-G patient XP125LO. Three of these changes are polymorphic variants whereas the remaining two, one in each XPG allele, inactivate complementation in vivo. These single point mutations provide formal proof that defects in XPG give rise to the group $\mathrm{G}$ form of xeroderma pigmentosum, and their locations suggest ways in which this may occur.

\section{INTRODUCTION}

The rare autosomal recessive disease xeroderma pigmentosum (XP) is characterized by sunlight-induced skin and eye lesions, skin cancers, and in some cases neurological abnormalities (1). Most patients fall into seven complementation groups $(A-G)$ that are thought to be due to defects in an early step of nucleotide excision repair (2). This pathway, which removes short patches of DNA containing a wide variety of lesions, has been extensively characterized in Escherichia coli (3) but much less is known of how it functions in eukaryotes. By now, genes that complement five of the seven classical XP groups (A-D and $G$ ) have been cloned (4-8). Some of these correspond to human ERCC genes that are able to correct the ultraviolet light (UV) sensitivity of certain rodent cell lines. Thus the $X P B$ and $E R C C 3$ genes are identical, as are $X P D$ and $E R C C 2$. All five cloned $X P$ genes also show significant similarity to DNA repair genes from Saccharomyces cerevisiae $(2,9)$, attesting to the importance of this repair pathway.

The one most recently characterized, $X P G$, is identical to

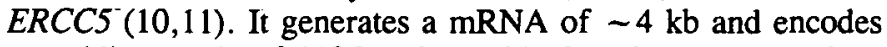
an acidic protein of 1186 amino acids that shares two regions of extensive homology with the yeast DNA repair protein RAD2. The XPG protein restores normal levels of UV resistance and unscheduled DNA synthesis when expressed in vivo in a lymphoblastoid cell line from an XP-G patient (8). The most straightforward interpretation of this finding is that defective $X P G$ alleles are responsible for the group $\mathrm{G}$ form of XP. It is formally possible, however, that the defects reside in another gene and that overexpressed XPG protein somehow is able to bypass the normal repair pathway. To distinguish between these possibilities and to try to define the molecular basis for this disorder, we have analysed $X P G$ cDNAs from an XP-G patient for the presence of mutations and for their effects on DNA repair in vivo.

\section{RESULTS}

Patient XP125LO expresses both XPG alleles

The $-4 \mathrm{~kb} X P G$ mRNA is present in normal amounts (8) in XPG83, a lymphoblastoid cell line (10) derived from XP-G patient XP125LO (12). We made two cDNA libraries from this cell line and screened them with XPG specific oligonucleotides. Seventeen clones were recovered, four of which were fully sequenced. These analyses revealed a total of six differences from the original XPG cDNA sequence (EMBL X69978).

The first was a $\mathrm{T} \rightarrow \mathrm{C}$ transition at position 335 . It represents a silent polymorphism at His 46 and it destroys a StyI restriction site. To confirm this point mutation and to determine its parental origin, we performed reverse transcription-polymerase chain reaction ( $R T-P C R$ ) on total RNA from cell lines from the proband and from her obligate heterozygote mother (XPG83 and XPG81, respectively; 10). Figure 1a shows that the expected 151 bp product containing the putative polymorphic site is amplified from both sources, that it is digested by StyI to yield $130 \mathrm{bp}$ and 21 bp bands in the case of the mother, but that a substantial fraction of the amplified DNA from the patient remains uncut. The incomplete digestion is not due to poor DNA quality because the RT-PCR product from the mother is fully cut by EcoRI, and by a mixture of StyI and EcoRI, whereas part of the patient DNA is again refractory to StyI under conditions in which $E c o$ RI cuts to completion (Fig. 1a). Analyses of genomic PCR products gave identical results (data not shown).

We conclude that patient XP125LO is heterozygous for this silent polymorphism, that she inherited the $T$ at position 335 from her mother, and that both alleles are expressed and yield similar levels of $X P G$ mRNA.

Patient XP125LO is homozygous for two more polymorphisms

The second $X P G$ sequence alteration was a $\mathrm{C}-\mathrm{G}$ transversion at position 3507 . This generates a $\mathrm{His} \rightarrow$ Asp substitution at amino acid 1104. It also creates a new MboIl site which permitted the RT - PCR analysis shown in Fig. $1 b$. The simultaneous presence of $136 \mathrm{bp}, 107 \mathrm{bp}$ and $29 \mathrm{bp}$ fragments in the sample from the mother indicates that she is heterozygous for the transversion, whereas her daughter is homozygous. Despite the nature of this substitution, it is unlikely to have a causative role in XP-G because it has been found in a functional ERCC5 cDNA sequence (11).

The third change was in the 3 ' untranslated region of $X P G$ at position 3842 . This $\mathrm{G} \rightarrow \mathrm{A}$ transition, $84 \mathrm{bp}$ beyond the TAA stop codon, is present in both alleles of the patient (data not shown) and also in ERCC5 cDNA (11). Hence, it too is unlikely to be implicated in the XPG clinical phenotype. 

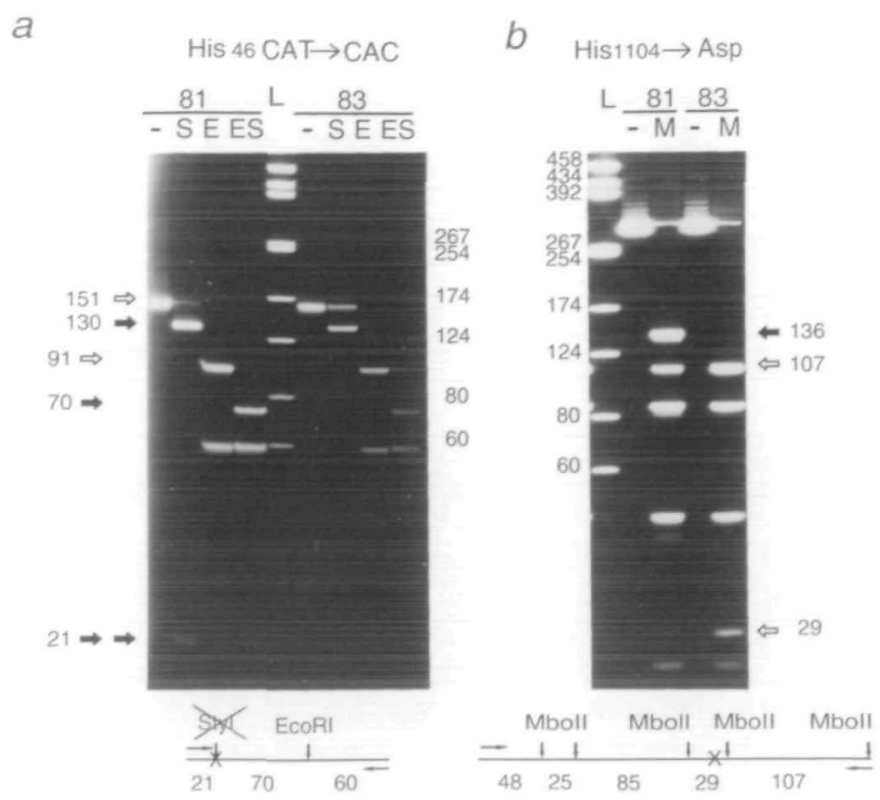

Figure 1. StyI and Mboll restriction analyses of RT-PCR products from lymphoblastoid cells from patient XP125LO (83) and her mother (81). - : Undigested XPG products. L: Hae III digest of pGEM3 DNA, with fragment lengths in bp. (a) S: Styl digestion. The inner open arrow indicates the undigested 151 bp RT - PCR product that lacks a StyI site (C/CWWGG) due to the T $\rightarrow$ C change at position $335(\mathrm{X})$. (The small amount of this band in the $S$ lane from the mother is due to partial digestion.) Inner filled arrows point at two StyI fragments of $130 \mathrm{bp}$ and $21 \mathrm{bp}$ derived from the second allele. E: control digestion with $E c o$ RI. ES: double digestion with $E c o$ RI and StyI. The outer open arrow indicates the 91 bp EcoRI fragment specific for the transition-carrying allele, and outer filled arrows point at $70 \mathrm{bp}$ and $21 \mathrm{bp}$ fragments resulting from Styl digestion. (b) $\mathrm{M}$ : $\mathrm{MboII}$ digestion. The $\mathrm{C}-\mathrm{G}$ transversion at position 3507 (X) creates a new MboII site (GAAGA[8/7], boxed), generating two fragments of 107 bp and $29 \mathrm{bp}$ (open arrows). The filled arrow points at the intact $138 \mathrm{bp}$ fragment derived from the second allele.

\section{A minor fraction of $X P G$ pre-mRNA is abnormally spliced} One cDNA derived from the paternal allele was found to be missing the $55 \mathrm{bp}$ from positions $1078-1132$. This introduces a frameshift that results, nine amino acids later, in a TGA stop codon. Such a truncated protein of 302 amino acids would certainly be expected to be non-functional. However, PCR amplification of this region reveals that a shorter product is present in only a minor fraction of the cDNA from both the proband and her mother (Fig. 2). It is absent, however, from their genomic DNA, suggesting that it is due to a splicing defect.

Sequence analysis of the genomic PCR products indeed reveals the presence of a $315 \mathrm{bp}$ intron located at the $5^{\prime}$ end of the deleted region (EMBL X78329). We speculate that the short mRNA results from aberrant splicing of this intron to a downstream cryptic acceptor site. Consistent with this idea, the $3^{\prime}$ end of the deleted region, $(\mathrm{Y})_{\mathrm{n}} \mathrm{CAG} / \mathrm{C}$ (Fig. 2), shows an excellent fit with the $3^{\prime}$ splice site consensus sequence; only the presence of a $\mathrm{C}$ instead of a purine in the first position of the 'exon' is somewhat unusual, but it is found in $13 \%$ of primate splice acceptor sites (14). To determine if this aberrant splicing is specific for this disorder, we performed RT-PCR on nine unrelated non-XP individuals. All nine generated the shorter product, in quite variable amounts (data not shown). We conclude that this aberrant splicing of XPG pre-mRNA is irrelevant to the XP phenotype.
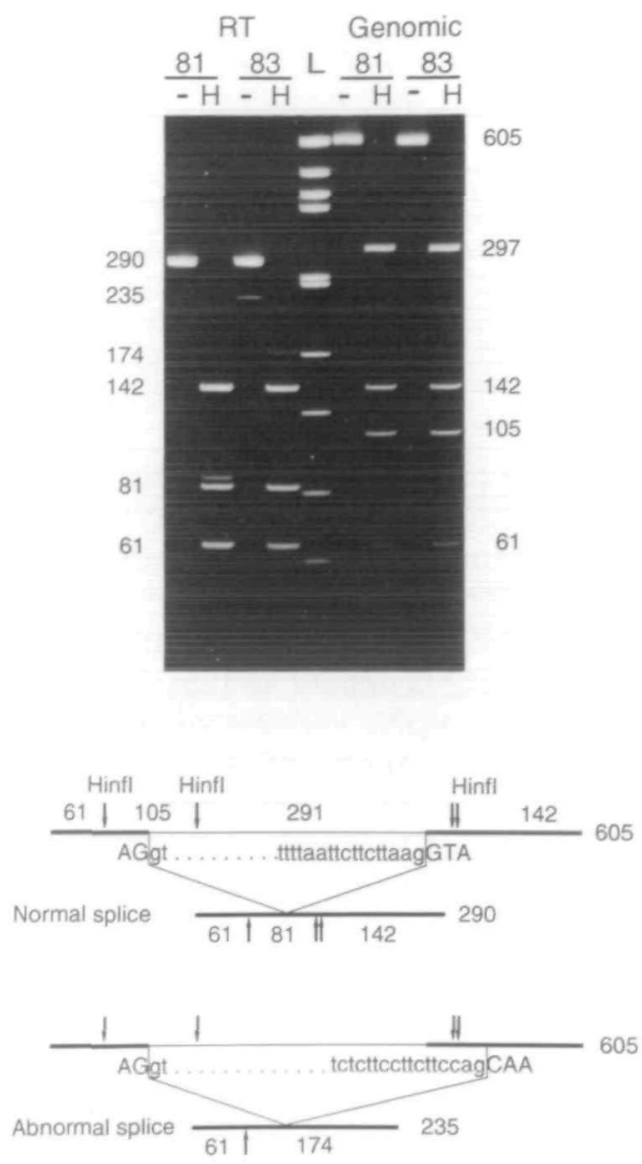

Figure 2. Hinfl restriction analyses of RT-PCR and genomic PCR products from lymphoblastoid cells from patient XP125LO (83) and her mother (81). -: Undigested XPG products. H: HinfI digestion. L: HaeIII digest of pGEM3 DNA. Genomic PCR generates a 605 bp band due to the presence of a $315 \mathrm{bp}$ intron located between positions 1077 and 1078 of the cDNA sequence. Splicing of this intron at the normal donor and acceptor sites results in a $290 \mathrm{bp} \mathrm{RT-PCR} \mathrm{product}$ which is cut by Hinfl to yield $142 \mathrm{bp}, 81 \mathrm{bp}$ and $61 \mathrm{bp}$ fragments; additional bands at $87 \mathrm{bp}$ and $148 \mathrm{bp}$ are presumed to be due to incomplete digestion at the two Hinfl sites 6 bp apart. Both cell lines also generate a minor 235 bp RT-PCR product and a minor 174 bp fragment after Hinfl digestion. These products can be explained by an occasional aberrant splicing event at the indicated cryptic acceptor site, thereby generating an XPG mRNA lacking positions $1078-1132$.

However, the presence of some shorter PCR product in every individual examined suggests that this 'leaky' splicing may contribute to the low abundance of functional XPG mRNA (8).

\section{Candidate nonsense and missense mutations}

The last two XPG sequence alterations found in patient XP125LO provided candidate mutations for her acute sun sensitivity. One is a $G \rightarrow T$ transversion at position 3075 (Fig. 3a) which transforms the Glu960 codon into a TAA stop codon and, in so doing, destroys a site for ApoI. This enzyme cuts the RT - PCR products from the mother to completion but only incompletely digests those of the proband (Fig. 3b); control incubations show that both DNAs can be digested to completion with BamHI. We conclude that this nonsense mutation would generate a truncated XPG protein of 959 amino acids and that it is carried by the paternal allele.

The candidate mutation in the maternal allele is a $\mathrm{C} \rightarrow \mathrm{T}$ transition at position 2572 (Fig. 3c) which causes an Ala $\rightarrow$ Val 

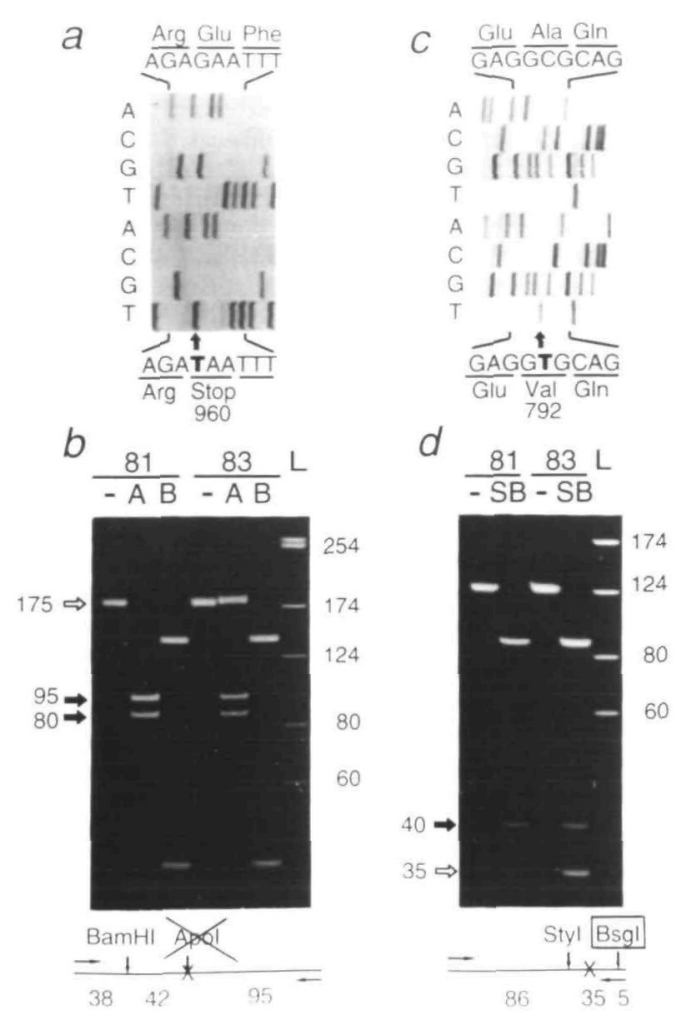

Figure 3. Paternal (left) and maternal (right) XPG mutations in patient XP125LO. (a) and (c). Nucleotide sequence of wild-type (top) and mutant (bottom) cDNAs showing (a) the $\mathrm{G}-\mathrm{T}$ transversion at position 3075 that generates a premature stop codon, and (c) the $\mathrm{C}-\mathrm{T}$ transition at position 2572 that leads to an amino acid substitution. (b) and (d) Restriction analyses of RT-PCR products from lymphoblastoid cells from the patient (83) and her mother (81). - : Undigested products. L: HaeIII digest of pGEM3 DNA, with fragment lengths in bp. (b) A: ApoI digestion. The open arrow points at a $175 \mathrm{bp}$ fragment that remains intact due to the destruction of the ApoI site (R/AATTY) by the mutation (X). Filled arrows show the $95 \mathrm{bp}$ and $80 \mathrm{bp} A p o I$ digestion products specific to the wild-type allele. B: control digestion with BamHI. (d) SB: double digestion with Styl and BsgI. The open arrow points at a $35 \mathrm{bp}$ fragment due to the new BsgI site (GTGCAG[16/14], boxed) created by the mutation $(X)$. The filled arrow points at the $40 \mathrm{bp}$ StyI fragment specific to the wild-type allele.

substitution at amino acid 792. This transition occurs within a $\mathrm{CpG}$, suggesting that it arose by deamination of 5-methylcytosine. Once again, the mutation creates a new restriction site, in this case for BsgI. Double digests of the RT - PCR products generate 35 bp StyI-BsgI and 40 bp StyI fragments (Fig. 3d), thereby showing that both the proband and her mother are heterozygous for this missense mutation.

The candidate mutations inactivate $X P G$ complementation activity

For functional tests, we cloned full length $X P G$ cDNAs containing each candidate mutation into EBO-pLPP, an Epstein-Barr virusbased episomal expression vector (15), and transfected them into XPG83 cells. After hygromycin selection, stable transfectants were challenged with UV, and their survival after $48 \mathrm{~h}$ was assayed with BCECF-AM, a carboxyfluorescein derivative that is hydrolysed to a fluorescent form by esterases within living cells (16).

Transfectants containing the EBO-pLPP vector alone are as highly sensitive to UV as untransfected cells, whereas the

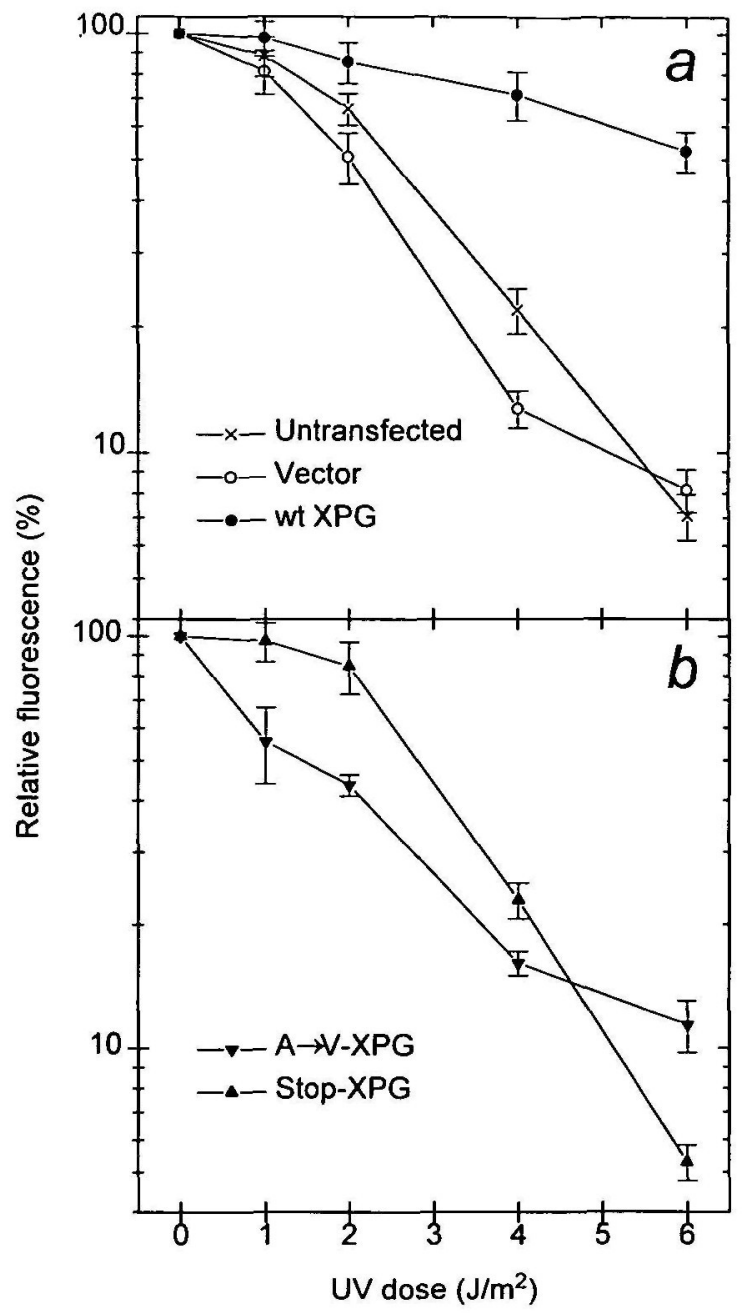

Figure 4. UV sensitivity of transfected lymphoblastoid XPG83 cells from patient XP125LO. (a) Untransfected cells (crosses), transfectants with EBO-pLPP vector alone (open circles), and transfectants with wild-type XPG cDNA in EBO-pLPP (filled circles). (b) EBO-pLPP-XPG transfectants carrying the patemal nonsense mutation (filled triangles), and EBO-pLPP-XPG transfectants carrying the maternal missense mutation (filled inverted triangles). Results are expressed as per cent of the BCECF fluorescence of non-irradiated cells. Error bars show the standard deviations of groups of four measurements.

presence of wild type $X P G$ cDNA restores. UV resistance to normal levels (Fig. 4a, and ref 8). Transfectants carrying the nonsense mutation at codon 960 appear to be slightly resistant at low UV doses but at higher doses are extremely UV sensitive (Fig. 4b). The seemingly innocuous $\mathrm{Ala} \rightarrow \mathrm{Val}$ substitution at codon 792 also has a severe effect; transfectants carrying this missense mutation show a similar UV sensitivity to those containing just the vector (Fig. 4b). We conclude that both mutations disable XPG and render it incapable of correcting the DNA repair defect in XPG83 cells.

\section{DISCUSSION}

Figure 5 summarizes our major findings: patient XP125LO inherited from her mother a missense Ala $\rightarrow$ Val mutation (\#2) located in the conserved I region of XPG. She is homozygous for a His $\rightarrow$ Asp polymorphism ( $\# 4)$ in the C-terminal part of 


\begin{tabular}{l} 
a \\
\cline { 3 - 6 }
\end{tabular}

Figure 5. Summary of the XPG alleles of patient XP125LO. (a) The XPG open reading frame is boxed and is flanked by $5^{\prime}$ and $3^{\prime}$ untranslated regions. The conserved $\mathrm{N}$ and I regions are hatched and the putative bipartite nuclear localization signal (NLS) is cross-hatched. $\Delta$ locates the 55 nucleotides missing in a minor fraction of XPG mRNA.Vertical bars and numbers locate the single nucleotide changes listed in the table. (b) Nucleotides are numbered from the XPG cDNA sequence (EMBL X69978). + and - indicate the presence or absence of a change in either allele of the proband (mat: maternal; pat: paternal) or her parents. In the case of the father, these are deductions (?: no deduction possible). Function indicates if transfection of a cDNA carrying that change corrects the UV sensitivity of XPG83 cells (nd: not determined).

the protein and for a $\mathrm{G} \rightarrow \mathrm{A}$ transition (\#5) in the $3^{\prime}$ untranslated region. Her paternal allele carries a silent $\mathrm{T} \rightarrow \mathrm{C}$ transition (\#1) in the conserved $\mathrm{N}$ region, and a nonsense mutation (\#3) that would generate a truncated XPG protein of 959 amino acids. Although the latter might represent a new germline mutation, paternal inheritance is highly likely because the proband has an affected brother, XP124LO, who has also been assigned to XP group G (12).

Two of these point mutations, the paternal nonsense and the maternal Ala $\rightarrow$ Val missense, lead to functional inactivation. They thus provide formal proof that $X P G$ is indeed the causative gene for XP group G. They also provide the initial information needed for a genetic screening test for this disorder. Moreover, as outlined below, their locations have potential implications for XPG function.

The truncated protein of 959 amino acids resulting from the paternal nonsense mutation would contain both the conserved $\mathrm{N}$ and I regions but not the putative bipartite nuclear localization signal or basic C-terminus (8). Conceivably, this shortened form of XPG might be active if it could bypass the requirement for nuclear entry. Alternatively, the loss of just the $\mathrm{C}$-terminus may be the critical event because such a deletion inactivates S.cerevisiae RAD2 (17). Use of an in vitro DNA repair assay $(18,19)$ should help to distinguish between these possibilities.

At first sight, it may seem surprising that the maternal Ala $\rightarrow$ Val substitution disables XPG complementing activity. However, Ala792 is located in a highly conserved 27 amino acid core within the I region of the RAD2 protein family, whose members include human XPG and its Xenopus laevis counterpart, S.cerevisiae RAD2 and YKL510, and Schizosaccharomyces pombe rad13 and rad2 $(8,11,20)$. In particular, this invariant Ala is flanked by glutamate residues that have been found in the active site of some DNA nucleases (8). That this core may indeed have functional significance is suggested by the recent finding of a DNA endonuclease activity intrinsic to S.cerevisae RAD2 (21). Clearly, a similar activity is anticipated for XPG, and we speculate that it is the endonuclease activity that is disabled by the maternal missense mutation in patient XP125LO.
With only seven known patients world-wide, XP group G is one of the rarest forms of this disorder. It is also one of the most clinically heterogeneous. Patient XP125LO and her affected brother have only mild cutaneous changes and no neurological abnormalities (12), whereas the first two patients belonging to this group exhibited severe XP pigmentation and mental retardation $(22-24)$. Recently, two very severely affected patients with neurological abnormalities characteristic of Cockayne's syndrome (CS) were assigned to XP group G $(25,26)$. This degree of clinical heterogeneity is surprising and not yet understood. Perhaps mildly affected patients possess some residual DNA repair activity despite their deficiencies in cellular repair assays. It is also possible that severely affected patients have mutations that inactivate a second function. In any event, we expect the two XP-G/CS patients to possess different mutations from those characterized here and we hope that their locations will also yield clues to functionally important domains within the XPG protein.

\section{MATERIALS AND METHODS}

\section{Cell lines}

The Epstein-Barr virus immortalized cell lines XPG83 from XPG patient XP125LO (12) and XPG81 from her mother were kindly provided by R.D.Wood. Cells were grown in suspension at $37^{\circ} \mathrm{C}$ in RPMI 1640 medium supplemented with $2 \mathrm{mM}$ glutamine and $10 \%$ fetal calf serum under $5 \% \mathrm{CO}_{2}$.

\section{cDNAs}

Twenty-five $\mu \mathrm{g}(\mathrm{dT})_{15}$ or $2 \mu \mathrm{g}$ of a specific primer complementary to $X P G$ positions 3815-3829 were phosphorylated with T4 polynucleotide kinase (Boehringer) and were separately annealed with $20 \mu \mathrm{g}$ poly $(\mathrm{A})^{+}$RNA. The RNA was a kind gift from D.Scherly and was prepared by lysing XPG83 cells into guanidinium isothiocyanate followed by cesium chloride step-gradient centrifugation and isolation on an oligo-dT cellulose column. cDNA synthesis was performed as described in the Superscript-Plus instructions (Gibco BRL) with minor modifications, using E.coli DNA Pol I and T4 DNA polymerase (New England Biolabs) and RNase $\mathrm{H}$ and $E$.coli DNA ligase (Boehringer). Two oligonucleotides (pTGGCCGTCGACTAC and pGTAGTCGACGGCCAGTG) were annealed together and $6.3 \mu \mathrm{g}$ were added to the cDNA and ligated overnight at $16^{\circ} \mathrm{C}$ in a total volume of $100 \mu \mathrm{l}$ using $32 \mathrm{U} / \mu \mathrm{l}$ T4 DNA ligase and $5 \%$ polyethylene glycol. The CDNA was fractionated on a 5-20\% sucrose gradient by centrifugation at $335000 \mathrm{~g}$ for $5 \mathrm{~h}$ at $4^{\circ} \mathrm{C}$. Aliquots were analysed on a $1 \%$ agarose gel, and fractions $>2.5 \mathrm{~kb}$ were pooled.

\section{Libraries}

The vector Bluescript $\mathrm{KS}^{+}$with a Sfi-CAT cassette (27) inserted in the EcoRV site was kindly provided by V.Steimle. The CAT stuffer was removed by digestion with Sfil and separation on a 5-20\% sucrose gradient, generating non-compatible termini. $680 \mathrm{ng}$ vector was ligated to the cDNA with $440 \mathrm{U} / \mu \mathrm{l}$ T4 DNA ligase at $20^{\circ} \mathrm{C}$ overnight then transformed into electro-competent bacteria (DH5 for the specific primer library, Sure cells (Stratagene) for the (dT) 15 library) with a GenePulser (Bio-Rad) set at $2500 \mathrm{~V}, 25 \mu \mathrm{F}, 200 \mathrm{Ohm}$. The libraries were titred and plated at 40000 colonies/dish on HATF filters (Millipore). $5 \times 10^{5}$ clones were plated from the specific library, and $10^{6}$ clones from the $(\mathrm{dT})_{15}$ library. Two replicas were made on BA85 filters (Schleicher \& Schuell) for hybridization screening.

\section{Hybridization}

Pairs of $\left[\gamma^{32} \mathrm{P}\right]-\mathrm{ATP}$ labelled oligonucleotides (positions $1-26$ and $1337-1312$ for the specific library, and positions $966-985$ and $2472-2492$ for the (dT) 15 library) were incubated with the filters in $5 \times$ SSC, $10 \times$ Denhard's, $20 \mathrm{mM}$ sodium phosphate ( $\mathrm{pH} 7.0$ ), 7\% SDS and $100 \mu \mathrm{g} / \mathrm{ml}$ herring sperm DNA, at $5^{\circ} \mathrm{C}$ below $\mathrm{T}_{\mathrm{m}}$ for $5 \mathrm{~h}$. After washing in $6 \times \mathrm{SSC}$ at $10^{\circ} \mathrm{C}$ below $\mathrm{T}_{\mathrm{m}}$ for $15 \mathrm{~min}$, positive clones were revealed by autoradiography, then recovered from the original HATF filters and submitted to a second round of purification. Purified clones were prepared by $\mathrm{CsCl}$ centrifugation and sequenced with a deaza-T7 sequencing kit (Pharmacia).

PCR restriction analysis

First strand cDNA was synthesized from $5 \mu \mathrm{g}$ total RNA with Superscript-Plus (Gibco-BRL) as specified by the manufacturer. Genomic DNA was prepared by 
digesting cells with $100 \mu \mathrm{g} / \mathrm{ml}$ proteinase $\mathrm{K}$ in $100 \mathrm{mM} \mathrm{NaCl}, 10 \mathrm{mM}$ Tris- $\mathrm{HCl}$ (pH 8.0), $25 \mathrm{mM}$ EDTA and $0.5 \%$ SDS at $50^{\circ} \mathrm{C}$ overnight. After phenol extraction and ethanol precipitation, samples were digested with $100 \mu \mathrm{g} / \mathrm{ml}$ RNase A for $1 \mathrm{~h}$ at $37^{\circ} \mathrm{C}$, then again extracted with phenol and precipitated with ethanol. PCR reactions $(50 \mu \mathrm{l})$ contained $1 / 8$ of the cDNA preparation or $250 \mathrm{ng}$ genomic DNA $100 \mathrm{ng}$ of each primer, $50 \mathrm{nM}$ of each dNTP, $1-2 \mathrm{mM} \mathrm{MgCl}_{2}$ and $4 \mathrm{U}$ AmpliTaq (Perkin-Elmer). Samples were first subjected to 10 touchdown cycles of: $30 \mathrm{~s}$ at $94^{\circ} \mathrm{C}, 30 \mathrm{~s}$ at $10^{\circ} \mathrm{C}$ above $\mathrm{T}_{\mathrm{a}}$, decreasing by $1{ }^{\circ} \mathrm{C}$ at each cycle, $30 \mathrm{~s}$ at $72^{\circ} \mathrm{C}$, and then to 20 standard cycles at calculated $T_{a}$. The following primer pairs were used: $312-333$ and $462-438,966-985$ and $1255-1236,2472-2492$ and 2597-2578, 2995-3015 and 3170-3149, 3330-3349 and 3624-3607. PCR products were phenol extracted, ethanol precipitated, digested with restriction enzymes, fractionated on $6 \%$ or $8 \%$ polyacrylamide gels then stained for $15 \mathrm{~min}$ with $100 \mu \mathrm{g} / \mathrm{l}$ ethidium bromide. The genomic PCR 291 bp and 105 bp Hinfl products (Fig. 2) were made flush-ended then cloned separately into the SmaI site of Bluescript $\mathrm{KS}^{+}$. Three clones of each were sequenced from $\mathrm{T} 3$ and $\mathrm{T} 7$ primers, yielding the sequence of a 315 bp intron (EMBL X78329) that disrupts XPG at the codon for Gly294.

\section{Transfection and UV survival assay}

Candidate mutations were introduced separately into a functional EBO-pLPP$X P G$ recombinant (8) by substituting appropriate $S t u I-B g I I I$ or SauI-StuI restriction fragments. XPG83 cells $\left(10^{7} / \mathrm{ml}\right)$ were transfected by electroporation with a Bio-Rad Gene Pulser at $250 \mathrm{~V}, 960 \mu \mathrm{F}$ in RPMI 1640 medium containing $20 \mu \mathrm{g} / \mathrm{ml}$ EBO-pLPP vector or recombinant DNA and $400 \mu \mathrm{g} / \mathrm{ml} E$.coli tRNA. Selection was achieved with increasing doses of Hygromycin B (Calbiochem) up to $200-250 \mu \mathrm{g} / \mathrm{ml}$. Selected cells were UV-irradiated at $254 \mathrm{~nm}$ in Hank's buffer at a flux of $12 \mu \mathrm{W} / \mathrm{cm}^{2}$ for increasing times. Duplicate $200 \mu \mathrm{l}$ samples were cultured with $1.4 \mathrm{ml}$ RPMI medium containing $10 \%$ inactivated fetal calf serum in 24-well plates. Forty-eight and $72 \mathrm{~h}$ later, $500 \mu \mathrm{l}$ aliquots were removed and incubated for $30 \mathrm{~min}$ with $1 \mu \mathrm{g} / \mathrm{ml} 2^{\prime}, 7^{\prime}$-bis-(2-carboxyethyl)-5-(and-6)carboxyfluorescein, acetoxymethyl ester (BCECF-AM, Molecular Probes). Cells were centrifuged for $5 \mathrm{~min}$ at $2000 \mathrm{~g}$ and resuspended in $250 \mu \mathrm{l}$ Hank's buffer plus $1 \%$ Triton $X-100$ at $4^{\circ} \mathrm{C}$. The fluorescence of duplicate $100 \mu \mathrm{l}$ aliquots was measured in 96-well plates in a Cytofluor (Millipore) with excitation/emission filters of $485 / 530 \mathrm{~nm}(16)$.

\section{ACKNOWLEDGEMENTS}

We are most grateful to D.Scherly, V.Steimle and R.D.Wood for materials, advice and critical comments on the manuscript, Janine Corlet for help with sequencing, and Glaxo IMB (Geneva) for access to their multiwell fluorimeter. This work was supported by grant 31-36481.92 from the Swiss National Science Foundation.

\section{ABBREVIATIONS}

CS, Cockayne's syndrome; ERCC, excision repair cross complementing; PCR, polymerase chain reaction; RT-PCR, reverse transcription-polymerase chain reaction; UV, ultraviolet light; $\mathrm{XP}$, xeroderma pigmentosum.

\section{REFERENCES}

1. Cleaver, J.E. and Kraemer, K.H. (1989) In Scriver, C.R., Beaudet, A.L., Sly, W.S. and Valle, D. (eds), The Metabolic Basis of Inherited Disease. McGraw-Hill, New-York, 6th edn, pp. 2949-2971.

2. Tanaka, K. and Wood, R.D. (1994) Trends Biochem. Sci. 19, 83-86.

3. Selby, C.P. and Sancar, A. (1993) Science 260, 53-58.

4. Tanaka, K., Satokata, 1., Ogita, Z., Uchida, T. and Okada, Y. (1989) Proc. Nall. Acad. Sci. USA 86, 5512-5516.

5. Weeda, G., van Ham, R.C.A., Masurel, R., Westerveld, A., Odijk, H., de Wit, J., Bootsma, D., van der Eb, A. and Hoeijmakers, J.H.J. (1990) Mol. Cell. Biol. 10, 2570-2581.

6. Legerski, R.J. and Peterson, C.A. (1992) Nature 359, 70-73.

7. Weber, C.A., Salazar, E.P., Stewart, S.A. and Thompson, L.H. (1988) Mol. Cell. Biol. 8, 1137-1146.

8. Scherly, D., Nouspikel, T., Coriet, J., Ucla, J., Bairoch, A. and Clarkson, S.G. (1993) Nanure 363, 182-185.

9. Prakash, S., Sung, P. and Prakash, L. (1993) Annu. Rev. Genet. 27, 33-70.

10. O'Donovan, A. and Wood, R.D. (1993) Nature 363, 185-187.

11. MacInnes, M.A., Dickson, J.A., Hemandez, R.R., Learmonth, D., Lin, G.Y., Mudget, J.S., Park, M.S., Schauer, S., Reynolds, R.J., Strniste, G.F. and Yu, J.Y. (1993) Mol. Cell. Biol. 13, 6393-6402.

12. Norris, P.G., Hawk, J.L. M., Avery, J.A. and Giannelli, F. (1987) Br. J. Dermatol. 116, $861-866$.
13. Saiki, R.K., Scharf, S., Faloona, F., Mullis, K.B., Hom, G.T., Erlich, H.A. and Arnheim, N. (1985) Science 230, 1350-1354.

14. Shapiro, M.B. and Senepathy, P. (1987) Nucleic Acids Res. 15, 7155-7174.

15. Spickofsky, N., Canfield, V. and Margolskee, R.F. (1990) DNA Prot. Eng. Techniq. 2, 14-18.

16. Leeder, J.S., Dosch, H-M., Harper, P.A., Lam, P. and Spielberg, S.P. (1989) Anal. Biochem. 177, 364-372.

17. Madura, K. and Prakash, S. (1986) J. Bacteriol. 166, 914-923.

18. Wood, R.D., Robins, P. and Lindahl, T. (1988) Cell 53, 97- 106.

19. Sibghat-Ullah, Husain, I., Carlton, W. and Sancar, A. (1989) Nucleic Acids Res. 17, 4471-4484.

20. Carr, A.M., Sheldrick, K.S., Murray, J.M., Al-Harithy, R., Watts, F.Z. and Lehmann, A.R. (1993) Nucleic Acids Res. 21, 1345-1349.

21. Habraken, Y., Sung, P., Prakash, L. and Prakash, S. (1993) Narure 366, $365-368$.

22. Cheesbrough, M.J. and Kinmont, P.D.C. (1978) Br. J. Dermatol. 99, Suppl. 16,61 .

23. Keijzer, W., Jaspers, N.G.J., Abrahams, P.J., Taylor, A.M.R., Arlett, C.F., Zelle, B., Takebe, H., Kinmont, P.D.C. and Bootsma, D. (1979) Mutat. Res. 62, 183-190.

24. Arlett, C.F., Harcourt, S.A., Lehmann, A.R., Stevens, S., Ferguson-Smith, M.A. and Morley, W.N. (1980) Carcinogenesis 1, 745-751.

25. Jaeken, J., Klocker, H., Schwaiger, H., Bellmann, R., Hirsch-Kauffmann, M. and Schweiger, M. (1989) Hum. Genet. 83, 339-346.

26. Vermeulen, W., Jaeken, J., Jaspers, N.G.J., Bootsma, D. and Hoeijmakers, J.H.J. (1993) Am. J. Hum. Genet. 53, 185-192.

27. Steimle, V., Otten, L.A., Zufferey, M. and Mach, B. (1993) Cell 75, $135-146$. 